TI 2000-021/3

Tinbergen Institute Discussion Paper

The Microfoundations of Macroeconomics

J eroen C.J .M. van den Bergh

John M. Gowdy 
Tinbergen Institute

The Tinbergen Institute is the institute for economic research of the Erasmus Universiteit Rotterdam, Universiteit van Amsterdam and

Vrije Universiteit Amsterdam.

Tinbergen I nstitute Amsterdam

Keizersgracht 482

1017 EG Amsterdam

The Netherlands

Tel.: +31.(0)20.5513500

Fax: $\quad+31 .(0) 20.5513555$

Tinbergen Institute Rotterdam

Burg. Oudlaan 50

3062 PA Rotterdam

The Netherlands

Tel.: $\quad+31 .(0) 10.4088900$

Fax: $\quad+31 .(0) 10.4089031$

Most TI discussion papers can be downloaded at

http://www.tinbergen.nl 


\section{The Microfoundations of Macroeconomics: An Evolutionary Perspective}

Jeroen C.J.M. van den Bergh

Department of Spatial Economics

Free University

De Boelelaan 1105

1081 HV Amsterdam, The Netherlands

jbergh@econ.vu.nl

and

John M. Gowdy

Department of Economics

School of Humanities \& Social Sciences

Rensselaer Polytechnic Institute

Troy, NY 12180-3590, USA

Lgowdy@aol.com 
March 13, 2000 


\begin{abstract}
We consider the microfoundations controversy from the perspective of economic evolution and show that the debate can benefit from lessons learned in evolutionary biology. Although the analogy between biology and economics has been noted before, it has rarely focused on clarifying the micro-macro distinction in economic theory and modelling. The macroevolution controversy in biology has generated testable theories such as the existence of punctuated equilibria in evolutionary history, the distinction between selection and sorting, and group selection. The micro-macro debate is further developed in biology than in economics due to a greater degree of specialisation and interaction of various sub-disciplines. The task for economists is to distinguish between insights directly relevant for economic theory and ones that hinge on unique features of biological systems. We argue that both micro and macro processes drive economic change and that macroeconomic change cannot be explained by micro level optimising alone. We show that debates in biology about group selection and punctuated equilibria are directly relevant to understanding economic evolution. The distinction between reductionism and holism is of little use and in its place a hierarchical approach is proposed. This allows for both upward and downward causation and interaction between levels. Specific topics incorporating ideas from evolutionary theory into economics are: economic exaptations, macroeconomic consequences of institutions, and group selection. Two insights are: selection (sorting) can occur at levels above the individual firm; and, macroeconomic theories can be formulated without reference to firm level descriptions. Micro and macro approaches to economic change are complementary.
\end{abstract}




\section{Introduction}

During the last quarter century the microfoundations approach to macroeconomic theory has become dominant. With the ascendance of the microfoundations approach the subject matter of macroeconomics has shifted steadily from questions of distribution and institutions to an almost exclusive concern with market efficiency in allocating goods and productive inputs. Pareto optimality has become the dominant goal of macroeconomic policy. On the other hand, a growing number of economists argue that the Walrasian microfoundation approach to macroeconomics is inadequate (Colander 1996, Foster 1987, Gintis and Romer 1998, Gowdy 1992, Hodgson 1993b). Even within the narrow framework of general equilibrium theory some basic problems exist with the microfoundations position (Weintraub 1977). For instance, applications of general equilibrium theory, as in computable or applied general equilibrium (CGE/AGE) models, do not follow a consistent micro approach because not every individual agent or market is described. Instead, CGE models assume, through aggregation or the assumption of representative individuals, that groups or sectors act analogously to a single rational individual, that is, they maximise a single-valued profit or utility function subject to some resource constraint.

Many other fundamental objections to the microfoundations approach have been raised. Evidence indicates that most individuals do not act strictly rationally, either in a static sense or according to the rational expectations' hypothesis (Twomey 1998). This is related to, among others, the fact that decision-making costs are positive and knowledge about the structure of the economy is imperfect (Becker 1965, Heiner 1982, Lancaster 1991). In addition, general equilibrium models that include realistic properties of behaviour and realistic descriptions of markets have no unique equilibria (Clower 1967, Hahn 1965, Leijonhufvud 1968, Radner 1968, 1970, Nicolaides 1988, and Dow 1997). There is thus no compelling reason to believe that a theory of macroeconomic change based on a microfoundation of strictly rational behaviour is adequate as a general theory of macroeconomics.

The level of aggregation necessary in macroeconomic models requires additional unrealistic assumptions such as fungibility, homogeneity of inputs and outputs, and linearity (see Scarth 1988, appendix A6). Aggregate capital and production functions cannot be logically derived from firm-level production functions (see Harcourt 1972 on the Cambridge capital theory controversy). Moreover, it must be assumed that aggregation is independent of policy in order to allow policy relevant models as an outcome. Aggregation can be done along various schemes, and choosing one is always somewhat arbitrary. For instance, consider the micro-level relationships $\mathrm{y}_{1}=\mathrm{f}_{1}\left(\mathrm{x}_{1}, \mathrm{x}_{2}\right)$ and $\mathrm{y}_{2}=\mathrm{f}_{2}\left(\mathrm{x}_{1}, \mathrm{x}_{2}\right)$. Aggregation of the $\mathrm{y}_{\mathrm{i}}$ into an aggregate variable $\mathrm{Y}$, and of the $x_{i}$ into an aggregate variable $X$, can occur via arbitrary functions $G$ and $H$, respectively: $Y=G\left(y_{1}, y_{2}\right)$, and $X=H\left(x_{1}, x_{2}\right)$. Straightforward aggregation functions are sums or weighted sums. Now suppose a unique macro-level relationship exists between $\mathrm{Y}$ and $\mathrm{X}$, say $\mathrm{Y}=\mathrm{F}(\mathrm{X})$. Then it follows that $\mathrm{Y}=\mathrm{F}(\mathrm{X})=\mathrm{F}\left(\mathrm{H}\left(\mathrm{x}_{1}, \mathrm{x}_{2}\right)\right)=\mathrm{K}\left(\mathrm{x}_{1}, \mathrm{x}_{2}\right)$, with $\mathrm{K} \quad \mathrm{F} \quad \mathrm{H}$. In addition, it is possible to derive the relationship between $\mathrm{Y}$ on the one hand, and $\mathrm{x}_{1}$ and $\mathrm{x}_{2}$ on the other hand, in another way, namely via $Y=G\left(f_{1}\left(x_{1}, x_{2}\right), f_{2}\left(x_{1}, x_{2}\right)\right)=J\left(x_{1}, x_{2}\right)$, with $J \quad G \quad\left[f_{1}, f_{2}\right] . K$ and $J$ are in general not identical, which contradicts the initial assumption of a unique macro-relationship between $\mathrm{Y}$ and $\mathrm{X}$. This means that there is no one-to-one link between micro and macro variables. 
Different approaches have been followed to solve this problem (see Janssen 1998). One is to set constraints on micro-level functions so that micro-level distribution plays no role in terms of macro-level outcomes, and no information is lost in the aggregation. Alternatively, restrictions can be placed on the values taken by the micro-level variables, based on marginal rules motivated by rational behaviour. Whichever path is taken, it is impossible for both aggregate variables to be equal to the sum of micro-level variables, and for macro relationships (e.g. sectoral production functions) to be analogous to micro-level counterparts (firm production functions). This suggests that it is futile to search for a definite and unique microfoundation for macroeconomic relationships. Micro- and macroeconomic theories and models should be regarded as complementary.

It is not the purpose of this paper to criticise microeconomic models, which we think have provided, and still may generate, many useful insights. We argue that microeconomic and macroeconomic models can provide independent and complementary descriptions of economies. We support this view by linking the micro-macro debate to a similar debate in evolutionary biology. Consequently, our discussion takes place within a context of evolutionary economic change and the forces that drive it. One central implication of this is that the criterion of "efficiency", which is central to the microfoundations interpretation of economic change, is much too narrow to describe the complex reasons for change in the macro economy (see Bromley 1990). Our motivation for considering the micro-macro debate in biology is that it has been discussed from many more angles, due to a more advanced specialisation, interaction between and integration of various subdisciplines, such as molecular biology (biochemistry), genetics, population theory, ecology and palaeontology.

The framework of evolutionary biology may enrich traditional economic analysis by taking into account a wider range of phenomena. As Hodgson (1995, xxi) argues: "Recognition of the shared problems of complexity in both biology and economics may lead economists to place less faith in methodological individualism and to recognise the legitimacy of levels and units of analysis above the individual." Consideration of recent controversies over micro and macro processes in evolutionary biology can shed light on parallel controversies in economic theory: (1) Biology provides a relevant description of evolutionary change using a delineation of hierarchies of selection and the movement up and down these hierarchies. This involves a range of theories, including Darwinian selection at the micro level as well as macro-level theories of sorting. (2) Evolutionary biology shows the explanatory power of focusing on group dynamics rather than regarding macro phenomena as simply the sum of the uncoordinated actions of individuals. Theories of group selection, and how the outcomes of group selection differ from individual selection, are well developed in biology. As in biology, co-operation as well as competition plays a fundamental role in economic evolution.

\section{Survival of the Fittest and Beyond: Parallel Controversies in Biology and Economics}

The field of evolutionary biology is today a major centre of activity in the philosophy of science, much as classical physics was the centre for most of this century. And if some fields of science 
are further along in their understanding of reality, related fields should make sure that their explanations are consistent with the latest discoveries and insights (Wilson 1998). Just as classical mechanics gave birth to the positivist philosophy of neo-classical economics, so too can evolutionary biology be the guide for new approaches to economics. Of course, any appeal to biology for insights into how economies work must be done with caution. The task for economists is to distinguish between insights that are directly relevant for economic theory, and those that hinge on unique features of biological systems. The latter may be either useless or stimulate new lines of thought.

Evolutionary theories have been central to both economics and biology for well over one hundred years. For the most part, however, applications of evolutionary theory by economists have been limited to rather crude applications of Darwinian natural selection. As Hodgson (1992, 1993a) points out, it was Herbert Spencer's "survival of the fittest" interpretation of Darwin that had the greatest impact on the formation of neo-classical economic thought. In biology also, for the first three-quarters of the twentieth century, the "Modern Synthesis" held sway with its emphasis on gradual change, competition, and adaptation. The view of evolutionary change held by biology was compatible with the corresponding orthodoxy in economics, the Neo-classical Synthesis. A long list of economists (Alchian 1950, Enke 1951, Friedman 1953, Hirshleifer 1977, Tullock 1979) used the analogy of natural selection to reinforce the neo-classical model and to argue for the superiority of market outcomes. For the most part, the application of evolutionary ideas to economics is still limited to fairly crude survival-of-the-fittest metaphors.

Although valiant attempts were made in the past to apply evolutionary theory to economics (Marshall 1898, Schumpeter 1949, Veblen 1898), the effort was hampered by the dominance of theories of evolution in biology that almost exclusively emphasised gradual change and adaptation at the margin, and minimised the importance of sweeping, discontinuous change (Hodgson 1993a). Schumpeter, among others, explicitly rejected biological analogies because at the time he was writing, biological evolution was seen as a slow, incremental process (Hodgson 1993a). Georgescu-Roegen (1989) argues that Schumpeter's views of economic evolution through gales of "creative destruction" anticipated current views of biological evolution as occurring in discontinuous jumps (Gowdy and Mesner 1998, Mesner and Gowdy 1999).

The emphasis of economic models on gradualism and optimisation began to be seriously challenged in the 1970s when heterodox economists such as Boulding (1970) and GeorgescuRoegen (1971) introduced the concept of entropy to describe economic change as an irreversible, thermodynamic process. A breakthrough in legitimising non-equilibrium approaches to evolutionary economics was the publication in 1982 of Nelson and Winter's "An Evolutionary Theory of Economic Change". This book paved the way for a variety of approaches to evolutionary economics, both near and remote from the mainstream. More recently, concepts from evolutionary biology such as path dependence (Arthur 1989, David 1985), self-organisation (Foster 1997, Witt 1998), and co-evolution (Brander and Taylor 1998, Norgaard 1992) are beginning to have an impact on economic thinking. Economists working with anthropologists and behavioural psychologists are developing realistic models of human behaviour in its social and biological context (Gintis 2000, Tversky and Kahneman 1974, 1981, Hodgson 1997). Even among heterodox economists, however, the opinion is still 
pervasive that methodological individualism is the preferred approach to economic problems and that economic change is progressive and driven by efficiency improvements at the margin.

The points of conflict in contemporary economics and evolutionary biology are remarkably similar. As in the field of economics, many prominent biologists decry the empty formalism of mathematical modelling (Mayr 1982). Others (Gould and Lewontin 1979) challenge the "Panglossian" view that all evolutionary change is for the better because it is the result of marginal improvements in "fitness". On the other hand, the "traditionalists" argue that micro-biological principles can explain all evolutionary change - including morphology, the complexities of individual behaviour, ecological relationships (co-evolution) and social behaviour (sociobiology) - and that there is no need for concepts of macroevolution (Dawkins 1976, Dennett 1995, Maynard Smith 1987).

Central features of the neo-Darwinian view of evolution by natural selection are: (1) sexual recombination and point mutation within structural genes are the main source of variability in organisms, and (2) evolutionary change is determined by natural selection working on variations in phenotype; those organisms that best fit their environment survive (Lewin 1980). The first statement implies that the pace of evolution is gradual and the second statement implies that the forces of adaptation determine the phenotype (morphology, physiology, behaviour, etc.) of an organism. Both statements are consistent with a micro-level approach to describing biological structure and changes therein. Two important higher-level theories of evolution have been proposed in addition to the traditional Darwinian selection of genes or individuals, namely group selection and punctuated equilibrium. Both these theories imply that there exist "higher level" selection processes, that is, higher than natural selection acting solely on individuals.

\section{Group Selection}

One of the most hotly debated topics in evolutionary biology is group selection, a concept whose definition has become increasingly slippery (Wynne-Edwards 1962, E.O. Wilson 1975, Ruse 1979, Sober 1981, Boyd and Richerson 1985, Trivers 1985, Alexander 1987, WynneEdwards 1991, D.S. Wilson 1997, Sober and Wilson 1998). Group selection means that the fitness of every member of the group depends on a group characteristic not isolated in an individual. Proponents of group selection argue that groups characterised by non-kin and nonreciprocal altruism may outcompete groups composed of selfish individuals or individuals showing only kin and reciprocal altruism. Opponents state that a basis for group inheritance is missing. Group selection challenges the neo-Darwinian view that all evolutionary change is driven by individual characteristics alone (Wynne-Edwards 1991). Its existence also challenges some of the basic assumptions underlying neo-classical utility theory and thus the microfoundations of welfare economics.

As recounted by Corning (1997) the first skirmish over group selection occurred in the 1960s with the publication of Wynne-Edwards (1962) book Animal Dispersion in Relation to Social Behaviour and the adverse reaction to it by Hamilton (1964a, 1964b), Williams (1966), and to a lesser extent E.O. Wilson (1975). Sociobiology provided a strong opposition against ideas about group selection, arguing that social behaviour is the result of genetic or individual selection (Wilson 1975; a more extreme version is Dawkin's (1976) selfish gene interpretation; a good assessment of the sociobiology debate is Ruse, 1979). Essential to sociobiological 
explanations of altruism are kin selection and reciprocal altruism, both of which attacked Wynne-Edward's formulation of group selection. Kin selection argued that apparently altruistic behaviour is genetically based because altruists are actually protecting their own genes by helping close relatives survive. Reciprocal altruism argued that apparent altruism was based on the expectation that favours would be returned.

For a few years after these exchanges any notion of group selection as a factor in evolution was considered to be unscientific. G.C. William's book "Adaptation and Natural Selection" (1966) was especially influential in debunking group selection. Sober and Wilson $(1998,5)$ write: "For the next decade [after the publication of William's book] group selection theory was widely regarded as not just false but as off-limits, as far as serious evolutionary thought was concerned." In the 1980s and 1990s, for a number of reasons, there has been a resurgence of interest in group or "multi-level" selection in biology (Wilson 1997) as well as social science (Boyd and Richerson 1985, White 1998).

With regard to group selection, sociobiologists argued that there is no clear mechanism to ensure that an advantageous pattern of change for the group is replicated by the actions of the individuals in the group. In other words, if a characteristic valuable to the group is not also of value for the individual or better the "gene" (directly or indirectly) then it will not be passed on. According to Boehm (1997), however, kin and reciprocal selection cannot explain generous acts towards non-kin that remain unreciprocated. Others argue that non-reciprocal and non-kin altruism is rare in animals and humans, and therefore group selection effects are weak, if they exist at all. Countering this claim are examples of supposedly non-kin based co-operation (Wilkinson 1990, Scheel and Packer 1991). The existence of social cognition among humans suggests that group selection in human populations and thus in economic systems may be more significant, due to the fact that possible individual behaviour is elicited or suppressed by culture.

An important element in the discussion about group selection and altruism is free rider behaviour. Free riders will profit from the benefits of being part of the group without having the traits that assure these benefits. When the relative proportion of free riders in the group increases the benefits of the group and the characteristics of group selection will slowly disappear. In other words, group selection may work as long as the free riders do not dominate the group. Suppression of free rider behaviour may occur when resource scarcity and competition is low (it is relatively easy to be altruistic), but it may be less present when the latter are high (altruism implies a serious sacrifice). Typically, selective pressure is higher in the second case, so that individual selection will leave more of an impact than group selection. In human groups selfish behaviour may be suppressed by a variety of social mechanisms and institutions. If co-operating groups of humans are more likely to survive than non-co-operating ones then it is not necessarily beneficial to the survival of genes or individuals to be strictly selfish.

Bowles and Gintis (1999b) use a game theoretic approach to demonstrate the evolutionary feasibility of "strong reciprocity", that is, co-operative behaviour not based on reciprocal altruism (weak reciprocity) or kin altruism. They use their experimental results, and case studies of hunting and gathering societies, to argue that sharing is as much "normal" human behaviour as is selfishness. Recent work in game theory using data from biology, anthropology and psychology has shown that the distinction between altruistic and non-altruistic co-operation is so blurred it is of little or no use. Behavioural research using game theoretic models show that 
co-operative behaviour is the outcome when realistic options are allowed such as continuous communication among players and retaliation toward free riders. As summarised by Gintis (2000) games such as The Ultimatum Game (Güth et al. 1982), The Public Goods Game (Isaac et al. 1994), and the Public Goods Game with Retaliation (Dawes et al. 1986) consistently show that co-operative, group-beneficial behaviour is pervasive in human groups. Boyd and Richerson (1992) argue persuasively that when retaliation (punishment for anti-social behaviour) is allowed almost any conceivable behaviour may evolve in large groups. Bowles and Gintis (1999a, 1999b) examine the economics of egalitarianism focusing on the evolution of group selection and strong reciprocity. Using data from a variety of human societies, they argue that "Homo reciprocans" is as distinctively human as "Homo economicus". As D.S. Wilson (1999) points out, evolutionary models predict that a single population will contain a variety of behavioural patterns. Commenting on Bowles and Gintis' (1999a) paper he writes:

Economic models also frequently predict mixed outcomes, but the image of human populations as a community of interacting behavioral strategies has not emerged as strongly from economic theory as from evolutionary theory. It is therefore gratifying that Bowles and Gintis emphasize the possibility of more than one human nature; human populations may consist of a spectrum from extreme altruists to extreme sociopaths. In addition to this theoretical plausibility, there is growing empirical evidence that a propensity to cooperate or exploit forms an important axis of human behavioral variation. Seeing human groups as both communities of interacting strategies and (partially) adaptive units deserves to become a major theme in the future.

Empirical research on group selection as well as game-theoretic models showing the advantages of co-operation has lent support to the group selection argument. When applied to human populations with complex socio-economic systems of rewards and punishment, group selection can add to the explanatory power of macroevolutionary theories and models. For example, Boehm (1997) argues that human institutions have had a great impact on our physical evolution. During most of our existence as a species we lived in small bands of hunter-gatherers (Lee and Daly 1999). Among these groups a highly stable "egalitarian syndrome" arose as a survival mechanism. Competition among males was reduced (see the articles in Gowdy 1998, Lee 1993) as well as the intensity of selection within the group, thereby reducing variation among phenotypes (Boehm 1997, S100).

Most of the literature on altruism-co-operation-selfishness in economics focuses on the consumer. Perhaps this is because the profit motive that drives production seems transparently individualistic. The existence of strong reciprocity in human behaviour casts doubt on the standard model of economic man in utility theory and thus microeconomic based concepts of social welfare. Numerous economists have called for a broader conception of social welfare to include institutions and collective goals. We next turn to the punctuated equilibrium debate, which like group selection presents a macro perspective on evolutionary change. 


\section{Punctuated Equilibrium}

The second higher-level, macro-level theory is that of "punctuated equilibrium" first formulated by Eldredge and Gould (1972). This theory has also been subject to much debate. When first proposed, this was not really a new theory but rather a new interpretation of palaeontological data. Eldredge and Gould merely claimed that the fossil record of "morphospecies" typically showed long periods of stasis interrupted by bursts of rapid change. As Gould and Eldredge (1993) point out, this finding is consistent with traditional explanations of evolution. Mayr (1959) and Wright (1931), for example, formulated gene-based theories of species evolution that could produce relatively rapid changes in phenotypes. The idea that the pace of evolutionary change might be rapid, need only supplement, not overturn, traditional theory. The radical implication of punctuated equilibrium is that it challenges the idea that natural selection is the only important mechanism of evolutionary change. Gould and Eldredge (1993) state that evolution is a hierarchical process with natural selection operating at the individual level but with other biological, climatic, and biogeochemical changes also responsible for the array of species and ecosystems present at any given historical moment. According to Gould and Eldredge it is the notion of hierarchical selection that really embodies the radical content of punctuated equilibrium because it challenges the notion that what now exists must be present because it has won the struggle for survival at the micro level.

Many concepts spawned by the punctuated equilibrium debate are directly relevant to economics. To capture the difference between micro and macroevolution Gould and Vrba (1982) distinguish between "sorting" and "selection". Sorting is a broad term that simply means differential survival rates. Some species survive while others do not for a number of reasons including "selection", that is, Darwinian selection due to competitive pressure. Selection is a cause while sorting is a broader term merely indicating an outcome. Sorting can occur at all levels not just among individuals (or genes) in biology and not just among firms (or production techniques) in economics. Moreover, causes of differential survival rates can flow up or down the hierarchy. Vrba and Eldredge (1984) and Vrba and Gould (1986) give the following examples of sorting: non-Mendelian sorting of genetic elements ("hitch-hiking genes"), punctuated equilibria, and extrinsic control due to different climatic and geological histories. Examples of downward causation include the effects of individual selection on gene frequencies; the influence of species selection on individual organisms, and hitch-hiking genes. Upward selection occurs when genes affect organisms, when organisms affect species, or when random genetic drift ultimately gives rise to a selective advantage that can become dominant in a small genetically isolated population (Prothero 1992).

Gould and Vrba argue further that the term "adaptation" is too broad to describe the reality of natural selection. They propose to use the word adaptation to describe "any feature that promotes fitness and was built by selection for its current role" (Gould and Vrba 1982, 6). They use the term "exaptation" to refer to features that "evolved for other uses (or for no

$$
\text { -opted' for their current role" (Gould and Vrba, 1982, 6). }
$$

Exaptations are fit for their current role but were not designed for it. Their presence is due to a combination of micro and macroeconomic events and processes. Current utility should not be confused with reasons for origin. More than semantic nitpicking is involved here. Gould and Lewontin (1979) argue that the emphasis on adaptation to the exclusion of all other concerns 
has led researchers to overlook vital aspects of evolutionary change including higher sorting process.

The distinction between adaptation and exaptation is critical in describing the economic world. There are innumerable examples of technologies and products that were designed for one thing and proved to be useful for another. A well-known case is Thomas Edison's invention of the phonograph while working on a machine that would record telegraphic impulses on paper discs (Mokyr 1990, 286). A more current case is the drug Viagara which was originally tested to treat angina and hypertension, until its well-known side-effects were reported by patients. Labour skills may also "evolve" for one function and prove to be useful for another function later. When the Ford motor company was founded in 1903 its first workers were drawn from the bicycle and carriage shops (Braverman 1974, 146). The assembly line was perfected in the automobile industry but was quickly adopted by a variety of other industries.

Pushing biological analogies a little further, institutions may also be seen as exaptations. Nelson and Pack (1999) argue that the success of Asian economies between 1960 and 1996 was due in large part to the fact that those countries had institutions which could assimilate modern technology. In Taiwan, for example, almost no electronic goods were produced in 1960, but by 1990 they amounted to 21 percent of manufacturing exports (Nelson and Pack 1999, 418). This kind of rapid adoption of new techniques and processes, requires entrepreneurs and workers with pre-existing skills that can be transferred to other activities.

The widespread acknowledgment of the existence of macroevolution is one of the most important contributions to come out of the punctuated equilibrium debate. That macro evolutionary outcomes cannot be explained solely by micro phenomena is widely accepted by biologists. A biologist generally unsympathetic with the punctuated equilibrium position, Francisco Ayala (1998, 128) writes:

Now, I pose the third question raised earlier: can macroevolutionary theory be derived from microevolutionary knowledge? The answer can only be "no." If macroevolutionary theory were deducible from microevolutionary principles, it would be possible to decide between competing macroevolutionary models simply by examining the logical implications of microevolutionary theory. But the theory of population genetics is compatible with both, punctualism and gradualism; and, hence, logically it entails neither...Hence, macroevolution and microevolution are decoupled in the sense (which is epistemologically most important) that macroevolution is an autonomous field of study that must develop and test its own theories.

The practice that Ayala rejects, that is, deciding between competing macro theories by examining the logical implications of micro theories is exactly the procedure invoked by neoclassical economists. In natural sciences researchers employ a variety of methods and techniques to examine different phenomena at different hierarchical levels. Molecular biologists, geneticists, and ecologists employ theories and empirical techniques appropriate for their subspecialities. In economics, however, attempts to establish independent explanations at the macro level are immediately subject to unrelenting efforts to reduce them to micro-type models. The best-known example is the reduction of Keynes' rich description of the macroeconomy to a 
sterile, mechanical system by Hicks (1939), Patinkin (1948), Samuelson (1947), and others. The punctuated equilibrium debate is relevant as a general lesson for the social sciences because it demonstrates that a separate theory of macroevolution is needed (see Somit and Peterson 1989). Since there is no obvious or certainly no unique economic analogue for the biological gene, in economic systems inheritance can occur in different ways and on different aggregation levels. This makes macroevolution in economics even more relevant than in biology.

Nevertheless, for the same reasons the opposition between individual or genetic selection versus "punctuationism" and sorting is less concrete and clear in an economic than in a biological context.

An interesting example of sorting at different levels in economics is given by Mokyr $(1990,13)$ who distinguishes between microinventions and macroinventions. Microinventions are those that involve small, incremental improvements in existing techniques already in use, while macroinventions are radical new changes without clear precedents in their new uses. For Moykr (1990, 13): "The essential feature of technological progress is that the macroinventions and microinventions are not substitutes but complements." A richer way of seeing this relationship is in terms of nested hierarchies (Simon 1962, Wollin 1999). Marginal and revolutionary processes work together in a complex network of bottom-up and top-down influence.

An example illustrating the complex and hierarchical interactions between institutions, technology, and economic evolution is Australia's wine industry (Wollin 1999). In a remarkably short period of time this industry grew from a mostly domestic enterprise producing an annual output valued at \$20 million (AU\$) in 1985/86, to an international industry producing an output valued at \$234 million (AU\$) in 1991/92. Wollin (1999) examines this success in the light of concepts from evolutionary biology. He cites a variety of factors that pre-adapted the Australian wine industry to take advantage of changing international tastes, technological advances, and institutional rigidities that made the European wine industries less able to adapt to new situations. New Australian wine drinkers were not bound by European traditions in wine drinking and were predisposed to experiment in new varieties and tastes. Australian winemakers were also free to experiment with new techniques of making wine and new grape varieties. Wollin $(1999,13)$ writes of the sudden surge in Australian international wine sales:

The old-world wine producers initially failed to respond to this new challenge. The new and smaller Australian industry group was able to innovate and take a significant share of markets at old-world producers' doorstep, whereas the European industry groups were bound by their traditions, regulations and institutional systems and unable to block the Australian initiative.

\section{Reductionism, Holism, Hierarchies and Macroevolution}

Many philosophers of science have regarded reductionism, decomposability, and disaggregation as problematic when applied to complex systems. Non-linear model theory has created doubts about the usefulness of striving for microfoundations to describe micro phenomena. It has shown that correct predictions are not possible, even with deterministic models, due to, among other things, non-linear chaos, bifurcations and catastrophes. Practical cases of modelling and 
theorising show that providing for more micro detail in a description of one compartment of a systems means economising on descriptive and disaggregate detail in another compartment of the same system. Reducing partiality in one dimension usually means increasing it in another.

Costanza et al. (1993) note that in theory and modelling a trade-off must be made between the criteria "generality", "precision", and "realism". Neo-classical microeconomics has emphasised generality and precision (see the discussion in E.O. Wilson 1998) whereas institutional and evolutionary economics stress realism. Holism can be defined as the notion that the whole is greater than the sum of its parts, a view denied by extreme reductionism and the neo-classical starting point of methodological individualism. Holism means that the characteristics of the whole cannot be derived from a complete knowledge of the parts. The implication is that reductionism will never provide all the answers to questions about the whole system's features. Features of the whole system are said to "emerge" in a deterministic sense. The degree of conflict between holism and reductionism depends on the definition of reductionism. If it includes understanding both the parts and the interactions between the parts which requires a decomposition of the whole into its parts - then reduction does not seem so antagonistic to understanding the whole. In many cases the reductionism-holism debate is not fundamental and the issue is instead how much complexity regarding interaction among parts is allowed in the description, and whether macro factors or processes may be approximately derived from micro processes. A hierarchical approach can resolve the "which-degree-ofreductionism" debate by understanding or explaining systems on multiple levels rather than reducing all phenomena to a single level, whether micro, macro or meso. In a hierarchical system entities and processes at one level can be made dependent on those at higher or lower levels (upward or downward causation).

The microfoundations controversy, and criticisms of the general equilibrium approach to economic theory, centres on how to explain economic change. Why does the configuration of economic entities differ between two points in time? The neo-classical answer is "efficiency"; those firms or techniques that are "fit", measured by the criteria of economic profit, survive and those that are not fit perish. A hierarchical explanation provides a more general framework in that it recognises the importance of efficiency at the micro level, but also recognises that there may be other factors driving economic change on other levels. Group selection and punctuated equilibria point to multiple levels of selection and imply a macroevolution that is not just microevolution scaled up.

As argued above evolutionary biology offers a reference point for developing a hierarchical perspective on macroeconomics. At the same time the rich history of evolutionary and institutional economics can be built upon. This includes the work of Marx, Veblen, Schumpeter, and Nelson and Winter. In addition, it covers theories of the evolution of hierarchical management organisations (North 1990, Simon 1962, Sah and Stiglitz 1986).

Today, however, most of the interesting work on economic hierarchies is being done in the field of management, not economics (Astley 1985, Betton and Dess 1985, Stewart 1997, Romanelli and Tushman 1994, Wollin 1999). The existing macroeconomic configuration can be seen as the result of the co-evolution of corporations, governments, and institutions creating an economic world favourable to survival of them. 


\section{Breaking the Microfoundations Impasse in Contemporary Economics}

Since its inception as a discipline with the publication of The Wealth of Nations over 200 years ago, there has been a steady narrowing of the subject matter of economics (Hodgson 1993a). The broad view of economics of Adam Smith has been steadily reduced to a theory of the allocation of scarce resources among alternative ends. The almost exclusive emphasis on efficiency has led to a conception of economic evolution analogous to the neo-Darwinian position in evolutionary biology. All change is the result of steady and progressive changes in efficiency at the level of the individual firm. Furthermore, the existing array of firms and techniques in a competitive economy must be the "best" in terms of efficiency since they have survived the natural selection game. The progress-as-efficiency view of the economic world has been enshrined in the microfoundations movement that began in earnest in the 1970s. Within most of mainstream economics explanations of economic change have been reduced to questions of efficiency improvements at the margin. We argue that macroeconomics should draw on advances in evolutionary biology to develop more general theories to explain the rich and varied world of real economic change.

Regardless of the ultimate outcome of the group selection and punctuated equilibrium debates in biology, it appears that higher-level theories make more sense in economics even than in biology. The reason is that economies lack a single selection level due to the fact that they do not have a unique physical inheritance unit comparable to the role of the gene in biological systems. As a result, change is less restricted by historical paths than in biology, and selection or better sorting may occur at various levels, including individual economic agents, stakeholder groups, sectors, products, institutions, cities, regions, countries, and so on. This implies that macro-level economic theories can be formulated without reference to lower level descriptions and that they may complement theories at both higher and lower levels. In this context the opposition of reductionism and holism is of little use. Instead, a hierarchical approach makes more sense, as it would allow for both upward and downward causation. The main implication of macro-level evolutionary theories is that they challenge the micro foundations argument that striving toward efficiency at the firm (or species or gene) level is the sole mechanism driving evolutionary change. This idea and the reaction to it is a central theme that can link contemporary evolutionary theory and economic theory.

\section{Acknowledgement}

We would like to thank Peter Mulder and Carl McDaniel for helpful comments. 


\section{References}

Alchian, A.A. 1950. Uncertainty, evolution and economic theory. Journal of Political Economy 58, 211-222.

Alexander 1987. The Biology of Moral Systems. Hawthorne, NY, Aldine de Gruyter.

Arthur, B. 1989. Competing technologies, increasing returns, and lock-in by historical events. Economic Journal 99, 116-131.

Astley, W. 1985. The two ecologies: population and community perspectives on organizational evolution. Administrative Science Quarterly 30, 224-241.

Ayala, F. 1998. Beyond Darwinism? The challenge of macroevolution to the synthetic theory of evolution. In: M. Ruse (ed.), Philosophy of Biology. Prometheus Books, Amherst, NY, pp. 118-135.

Becker, G. 1965. A theory of the allocation of time. Economic Journal 75, 493-517.

Bergh, J.C.J.M. van den, and J.M. Gowdy 2000. Evolutionary theories in environmental and resource economics: approaches and applications. Environmental and Resource Economics, forthcoming.

Betton, J. and G. Dess 1985. The Application of Population Ecology Models to the Study of Organizations. Oxford University Press, New York.

Boehm, C. 1997. Impact of the human egalitarian syndrome on Darwinian selection mechanisms. The American Naturalist 150 (Supplement): S100-S121.

Boulding, K. 1970. Economics as a Science. McGraw-Hill, New York.

Bowles, S. and H. Gintis. 1999a. Is equality passé? Boston Review 23.

Bowles, S. and H. Gintis. 1999b. The evolution of strong reciprocity. mimeo. University of Massachusetts, Amherst, MA.

Boyd R., and P.J. Richerson, 1985. Culture and Evolutionary Process. University of Chicago Press, Chicago.

Boyd, R. and P.J. Richerson 1992. Punishment allow the evolution of cooperation (or anything else) in Sizable Groups. Ethology and Sociobiology 113, 171-195.

Brander, J. and Taylor, S. 1998. The simple economics of Easter Island: A Ricardo-Malthus model of renewable resource use. American Economic Review, 88(1), 119-138.

Braverman, H. 1974. Labor and Monopoly Capital. Monthly Review Press, New York.

Bromley, D.W. 1990. The ideology of efficiency: searching for a theory of policy analysis. Journal of Environmental Economics and Management 19, 86-107.

Clower, R. 1967. A reconsideration of the microfoundations of monetary theory. Western Economic Journal 6, 1-8.

Colander, D. 1996. Overview. In: D. Colander (ed). Beyond Microfoundations. Cambridge University Press, New York.

Corning, P.A. 1997. Holistic Darwinism: "Synergistic selection" and the evolutionary process. Journal of Social and Evolutionary Systems 20(4), 363-400.

Costanza, R., L. Wainger, C. Folke and K.-G. Mäler 1993. Modeling complex ecological economic systems. BioScience 43, 545-555.

David, P. 1985. Clio and the economics of QWERTY. American Economic Review Proceedings 75, 332-337. 
Dawes, R.M., J.M. Orbell and J.C. van de Kragt 1986. Organizing groups for collective action. American Political Science Review 80, 1171-1185.

Dawkins, R. 1976. The Selfish Gene. Oxford University Press, New York.

Dennett, D. 1995. Darwin's Dangerous Idea: Evolution and the Meanings of Life. Simon and Schuster, New York.

Dow, S. 1997. Mainstream economic methodology. Cambridge Journal of Economics 21, 73-93.

Eldredge, N. and Gould, S.J. 1972. Punctuated equilibria: an alternative to phyletic gradualism. In Schopf, T.J.M.(ed.) (1972), Models in Paleobiology. Freeman Cooper, San Francisco, 82-115.

Enke, S. 1951. On Maximizing profits: A distinction between Chamberlin and Robinson, American Economic Review 41, 566-578.

Foster, J. 1987. Evolutionary Macroeconomics. Allen and Unwin, London.

Foster, J. 1997. The analytical foundations of evolutionary economics: From biological analogy to economic self-organization. Structural Change and Economic Dynamics 8(4), 427 452.

Friedman, M. 1953. On the methodology of positive economics. In: M. Friedman, Essays in Positive Economics. Chicago, University of Chicago Press.

Georgescu-Roegen, N. 1971. The Entropy Law and the Economic Process. Harvard University Press, Cambridge, MA.

Georgescu-Roegen, N. 1989. Quo vadis homo sapiens sapiens? Mimeo. Duke University, Georgescu-Roegen collection.

Gintis, H. 2000. Game Theory Evolving. Princeton University Press, Princeton, NJ.

Gintis, H. and Romer, P.. 1998. The human side of economic analysis: Economic environments and the evolution of norms and preferences. Department of Economics, University of Massachusetts, mimeo.

Gould, S.J. and Eldredge, N. 1993. Punctuated equilibrium comes of age. Nature 366, 223227.

Gould, S. J. and R. Lewontin 1979. The spandrels of San Marco and the Panglossian paradigm. Proceedings of the Royal Society of London B 205, 581-598.

Gould, S.J. and Vrba, E. 1982. Exaptation - A missing term in the science of form. Paleobiology 8, 4-15.

Gowdy, J. 1992. Higher selection processes in evolutionary economic change. Evolutionary Economics 2, 1-16.

Gowdy, J. (ed.) 1998. Limited Wants, Unlimited Means: A Hunter-Gatherer Reader on Economics and the Environment. Island Press, Washington, D.C.

Gowdy, J. and Mesner, S. 1998. The evolution of Georgescu-Roegen's bioeconomics. Review of Social Economy 56(2), 136-156

Güth, W., R. Schmittberger and B. Schwarz. 1982. An experimental analysis of ultimate bargaining. Journal of Economic Behavior and Organization 3, 367-388.

Hahn, F. 1965. On some problems of proving the existence of an equilibrium in a monetary economy. In F.H. Hahn and F. Brechling, The Theory of Interest Rates. MacMillan, London. 
Hamilton, W.D. 1964a. The genetical evolution of social behavior I. Journal of Theoretical Biology 7,1-16.

Hamilton, W.D. 1964b. The genetical evolution of social behavior II. Journal of Theoretical Biology 7, 17-52.

Harcourt, G. 1972. Some Cambridge Controversies in the Theory of Capital. Cambridge University Press, London.

Heiner, R. 1982. The origin of predictable behavior. American Economic Review 73, 560595.

Hicks, J.R. 1939. Value and Capital. Oxford University Press, Oxford.

Hirshleifer, J. 1977. Economics from a biological viewpoint. Journal of Law and Economics 20(1), 1-52.

Hodgson, G. 1992. Thorstein Veblen and post-Darwinian economics, Cambridge Journal of Economics 16, 285-301.

Hodgson, G.M., 1993a. Economics and Evolution: Bringing Life Back Into Economics. University of Michigan Press, Ann Arbor.

Hodgson, G. 1993b. Why the problem of reductionism in biology has implications for economics. World Futures 37, 69-90.

Hodgson, G. (ed.) 1995. Economics and Biology. Aldershot, Edward Elgar.

Hodgson, G. 1997. The ubiquity of habits and rules. Cambridge Journal of Economics 21, 663-684.

Isaac, R.M., J.M. Walker and A.W. Williams 1994. Groups size and voluntary provision of public goods: experimental evidence utilizing large groups. Journal of Public Economics 54, 1-36.

Janssen, M.C.W. 1998. Aggregation. In: J.B. Davis, D.W. Hands and U. Mäki (eds.). The Handbook of Economic Methodology. Edward Elgar, Cheltenham.

Lancaster, K. 1991. Modern Consumer Theory. Edward Elgar, Vermont.

Lee, R. 1993. The Dobe Ju/'hoansi. Harcourt Brace, Fort Worth.

Lee, R. and R. Daly. 1999. The Cambridge Encyclopedia of Hunter-Gatherers. Cambridge University Press, Cambridge, UK.

Leijonhufvud, A. 1968. On Keynesian Economics and the Economics of Keynes. Oxford University Press, New York.

Lewin, R. 1980. Evolutionary Theory Under Fire. Science 210, 883-887.

Marshall, A. 1898. Mechanical and biological analogies in economics. Reprinted in A.C. Pigou (ed.), Memorials of Alfred Marshall. New York, A.M. Kelly.

Maynard Smith, J. 1987. Darwinism stays unpunctuated. Nature 330, 516.

Mayr, E. 1959. Isolation as an evolutionary factor. Proceedings of the American Philosophical Society 103, 221-230.

Mayr, E. 1982. The Growth of Biological Thought. Harvard University Press, Cambridge, MA.

Mesner, S. and Gowdy, J. 1999. Georgescu-Roegen's evolutionary economics. In: K. Mayumi and J.Gowdy (eds.), Bioeconomics and Sustainability: Essays in Honor of Nicholas Georgescu-Roegen. Edward Elgar, Cheltenham.

Mokyr, J. 1990. The Lever of Riches. Oxford University Press, New York. 
Nelson, R. and H. Pack. 1999. The Asian Miracle and Modern Growth Theory. Economic Journal 109, 416-436.

Nelson, R. and Winter, S. 1982. An Evolutionary Theory of Economic Change. Harvard University Press, Cambridge, MA.

Nicolaides, P. 1988. Limits to the expansion of neoclassical economics. Cambridge Journal of Economics 12, 313-328.

Norgaard, R. 1992. Coevolution of Economy, Society and Environment. In: P. Ekins and M. Max-Neef (eds.), Real Life Economics. Routledge, London.

North, D.C., 1990. Institutions, Institutional Change and Economic Performance. Cambridge University Press, Cambridge.

Patinkin, D. 1948. Price flexibility and full employment. American Economic Review 38, 543564.

Prothero, D.R., 1992. Punctuated equilibrium at twenty: a paleontological perspective. Skeptic 1(3): 38-47.

Radner, R. 1968. Competitive equilibrium under uncertainty. Econometrica 36, 31-58.

Radner, R. 1970. Problems in the theory of markets under uncertainty. American Economic Review 60, 454-60.

Romanelli, E. and M. Tushman. 1994. Organizational transformations as punctuated equilibrium: an empirical test. Academy of Management Journal 37 (5), 1141-1166.

Ruse, M., 1979. Sociobiology: Sense or Nonsense. Reidel Publishing Co., Dordrecht.

Samuelson, P.A. 1947. Foundations of Economic Analysis. Harvard University Press, Cambridge, MA.

Sah, R.K., and J.E. Stiglitz, 1986. The architecture of economic systems: hierarchies and polyarchies. American Economic Review 76(4), 716-727.

Scarth, W.M. 1988. Macroeconomics: An Introduction to Advanced Methods. Harcourt Brace Jovanovich, Toronto.

Scheel, D. and C. Packer. 1991. Group hunting behavior of lions: A search for cooperation. Animal Behavior 41, 697-710.

Schumpeter, J. 1949. The Theory of Economic Development. Harvard University Press, Cambridge, MA.

Simon, H. 1962. The architecture of complexity. Proceedings of the American Philosophical Society 106, 467-82.

Sober, E. 1981. Holism, individualism, and the units of selection. In: P.D. Asquith and R. N. Giere (eds.) (1981) Philosophy of Science Association 1980, vol. 2, Philosophy of Science Association, East Lansing, MI, 93-121.

Sober, E. and D. S. Wilson. 1998. Unto Others: The Evolution and Psychology of Unselfish Behavior. Harvard University Press, Cambridge, MA.

Somit, A. and S. Peterson 1989. The Dynamics of Evolution: The Punctuated Equilibrium Debate in the Natural and Social Sciences. Cornell University Press, Ithaca, NY.

Sonnenschein, H. 1988. Oligopoly and game theory. In: The New Palgrave Dictionary of Economics, MacMillan, London.

Stewart, J. 1997. Evolutionary progress. Journal of Social and Evolutionary Systems 20(4), 335-362. 
Trivers, R.L. 1985. Social Evolution. Menlo Park California, Benjamin-Cummings.

Tullock, G. 1979. Sociobiology and economics, Atlantic Economic Journal 220S, 1-10.

Tversky, A. and Kahneman, D. 1974. Judgment under uncertainty: Heuristics and biases. Science 185. 1124-1131.

Tversky, A. and Kahneman, D. 1981. The framing of decisions and the psychology of choices. Science 211, 453-458.

Twomey, P. 1998. Reviving Veblenian economic psychology. Cambridge Journal of Economics 22, 433-448.

Veblen, T. 1898. Why is economics not an evolutionary science? Quarterly Journal of Economics 4, 373-397.

Vrba, E. S. and N. Eldredge 1984. Individuals, hierarchies and processes: towards a more complete evolutionary theory. Paleobiology 10(2), 146-171.

Vrba, E. and Gould, S. 1986. The hierarchical expansion of sorting and selection: sorting and selection cannot be equated. Paleobiology 12, 217-228

Weintraub, E. R. 1977. The microfoundations of macroeconomics: a critical survey. Journal of Economic Literature 15(1), 1-23.

White, R. 1998. Toward the 'New Synthesis: Evolution, Human nature, and the Social Sciences. Choice Magazine (September), 1-20.

Wilkinson, G.S. 1990. Food Sharing in Vampire Bats. Scientific American 262, 76-82.

Williams, G.C. 1966. Adaptation and natural Selection. Princeton University Press, Princeton, NJ.

Wilson, D.S., 1997. Introduction: Multilevel selection theory comes of age. The American Naturalist 150 (July, Supplement), S1-S4.

Wilson, D. S. 1999. Evolutionary Support. Boston Review 23.

Wilson, E.O. 1975. Sociobiology: The New Synthesis. Harvard University Press, Cambridge, MA.

Wilson, E.O. 1998. Consilience. Alfred Knopf, New York.

Witt, U. 1998. Self-organization and economics - what is new? Structural Change and Economic Dynamics 8(4), 489-501.

Wollin, A. 1999. New wine into old markets: A multilevel, punctuated-equilibrium view of international macro-entrepreneurship. Graduate School of Management, University of Queensland, Australia, mimeo.

Wright, S. 1931. Evolution in Mendalian Populations. Genetics 16, 97-159.

Wynne-Edwards, V. 1962. Animal Dispersion in Relation to Social Behavior. Oliver and Boyd, Edinburgh.

Wynne-Edwards, V. 1991. Ecology denies neo-Darwinism. The Ecologist, 21, May/June. 